\title{
Russian Language Community and its Mass Manifestations
}

\author{
Igor E. Kim* \\ Institute of Philology of the SB RAS \\ 8 Nikolaeva Str., Novosibirsk, 630090, Russia
}

Received 25.11.2016, received in revised form 15.12.2016, accepted 11.01.2017

\begin{abstract}
The paper concerns the manifestations of the most extensive philological practices in the Russian language community, such as the reforms of the Russian orthography and the "Total Dictation", the latter being an annual event involving a large Russian-speaking audience all over the world. The reforms of the Russian orthography are the most similar to the Total dictation in the scale of the Russian language community involvement. The comparison of the Total dictation with the reforms of the Russian orthography shows that the functions of the Russian language community members are different in each practice. The Total dictation presents the new roles for the members of the language community in the philological practice: the role of the dictation author, who combines the featurepublicist content with the set language forms, and the role of a philological manager. The Total dictation demonstrates the mass participation of the "silent majority" (A.Ia. Gurevich) of the Russian language community.
\end{abstract}

Keywords: Russian language community, orthography reform, Total dictation, philological practice.

DOI: 10.17516/1997-1370-0004.

Research area: philology.

Russian sociolinguistics uses the term communication environment (for example, it is used in the research field) (Avrorin, 1975). The internal form of the term deprives the language group seen as communication environment of such an important characteristic feature as its activity towards language. The matter is if there exists a more conscious part of the Russian language community, which is active towards language, voluntary when choosing linguistic means, concerned about internal and external issues of language existence itself and language existence of ethnos. It is convenient to use the term Russian language community for this part of the Russian language group.

Outlining the Russian language community I mean an implicitly defined Russian-speaking community, the members of which are united due to the fact that they value their language existence and language presence in the society.

The Russian language community is potential; its existence in usual conditions is invisible and obscure. The majority of its representatives can be referred to as the "silent majority". The image of the "silent majority" was introduced to the humanities by A.Ia. Gurevich,

(c) Siberian Federal University. All rights reserved

* Corresponding author E-mail address: kimkim271060@yahoo.com 
one of his books having "The Medieval World: the Culture of Silent Majority" title (Gurevich, 1990). This notion directly correlates with A.S. Pushkin's last phrase in "Boris Godunov": People are silent. It surprisingly helps to understand one of the key research methods of mass public conscience. This method was widely used by the researchers of the past periods of society life when the researchers had no opportunity to address the members of the society directly. The conception of power, social organization of society made by illiterate or not included into the documental communication part of society is studied via different sources. These sources include the peasants' complaints to the governmental bodies in the XIX century (Litvak, 1971) or the materials of the criminal cases in the XVII century (Lukin, 2000). For us it is much more important that this "silent majority" of the society becomes jointly active only in the significant moments of the national history.

The language community should manifest itself in order to be clearly and fully seen. This manifestation should be communicative and publicly-massive. The manifestations include the following forms:

1. Internet-communities, forums permanent existence of small parts of language community embodied in mutual communication, see, for example, the analysis of some topics from one of such Internet-communities in the studies (Basalaeva, Shpil'man, 2015; Basalaeva, Ruzha, Shpil'man, 2016).

2. Communication with language portals, services, for instance, GRAMOTA RU (gramota. ru) or "Culture of writing" (gramma.ru). This communication shows permanent existence as well, but that is the existence of the individuals members of the community. This communication is partially connected with the professional concerns of specialists or learning requirements of pupils and students. Yet, many issues are discussed just because of someone being "curious".

3. Language changes more often have an uneven character: there are sudden and abrupt reforms or changes of language situation. Many members of the language community still discuss the impending death of the Russian language, purity of the Russian language and its protection from the destructive influences of foreign languages. It can be assumed that Iu.N. Karaulov's report (1991) initiated the discussions about the state of the post-Soviet Russian language. Apocalyptic feeling that the Russian language would disappear soon was evoked by the language situation of the $90 \mathrm{~s}$ when the system of regulation in public and mass communication in Russia was destroyed along with the socialistic state system and communist ideology. It led to the penetration of criminal jargon and colloquial Americanisms into public and mass communication. The intensity of these language processes gave rise to the protests of the language community. The official language reforms spark irritation as well. Due to their style features such reforms might be applied mostly to writing and, first of all, to orthography as its standard aspect. The discreet, uneven reform fixing the changes in spelling rules turns the majority of the language group from the literate into illiterate ones in different aspects. People connected with language creativity react to these changes most painfully. These people are writers, for whom the language is an instrument like paints and brushes for artists. Journalists, literature editors and proof-readers do also react but to a lesser extent.

4. Different events, for example, promoted by the government, such as the calendar periods of the Russian language support ${ }^{1}$. The events of this kind are usually financially supported from the budget and they, as a rule, attract administrative managers, sometimes of a really high status. 
The forms of community members' participation are various: surveys (passive form), papers, discussions, interviews, posts in blogs and social networks, commenting the posts, presentations of linguistic literature.

It is worth while making an attempt to stratify the Russian language community.

It is necessary to outline that there are two characteristics of stratification orthogonal to each other. The first characteristic is the degree of linguistic qualification and language competence. The second characteristic is a creative and analytic nature of approaching the language, which is necessary for a high qualification degree.

According to the first characteristic, the community can be divided into the following groups:

1) Specialists in Russian philology, scholars and university professors. They can be further stratified by an academic degree, position and rank, scientific and teaching experience;

2) Teaching materials developers and school teachers of the Russian language ${ }^{2}$;

3) Creative literary workers ${ }^{3}$, namely, writers, journalists, literary men creating written texts; radio and TV announcers, TV presenters, Djs and Vjs, theatre, cinema, TV actors taking part in oral communication; public relations specialists are all-round specialists dealing with analytic work with the text as well. The distinctive feature of all these specialists' work is public, or even mass nature of activity;

4) Practical philologists, namely, copy editors and proof-readers, publishers, copywriters, web writers and speechwriters ${ }^{4}$ - intermediate members of public and mass communication;

5) Programmers dealing with the development and implementation of the software for linguistic needs: translation, spelling checking and studying systems;

6) Students of philology, the majority of whom are, apparently, specialists in the Russian language;
7) Communication workers: politicians, managers, officials, real estate agents, nonphilological professors and other communication workers who should have communication skills but don't necessarily have philological education.

8) The Russian language lovers - silent majority (not in the communication sense but in their attitude towards language) of the Russian language community. The degree of communication activity is not so low owing to the Internet and language services. Due to the Internet the communication of the "ordinary" native speakers with the language services is often mass and public one.

The border between specialists and ordinary members of the community most likely lies around the group of the students studying philology. Though they are not philologists yet, they internally take linguistic self-awareness. They are not always ready to realize this linguistic self-awareness as they are involved in active philological social practices as mere recipients.

Speaking about "the creative work with the language", we should mark out "the writers" presenting the third and partially the fourth groups. The writers' linguistic activity is of a creative nature as they write original texts 5 . Copywriters, speechwriters and other "writers" differ from writers and journalists as their authorship is anonymous.

The orthography reforms are the largest practices among the mentioned above social practices which the language community can use to manifest themselves. Considering the experience of the $\mathrm{XX}$ and the beginning of the XXI centuries this practice is the greatest regarding the community members' involvement. It is very hard for a non-specialist to understand the spontaneous large-scale language changes in the time of reforms. Thus, mostly linguists and writers speak and write 
about the future of the language publicly. It is easier to understand the reforms referring to the particular rules of orthography. Besides, the orthography reforms, as a rule, are widely discussed in the mass media beforehand. Due to the coverage in the mass media these reforms get lots of preliminary feedbacks from the language community.

The experience of such discussions has been analyzed in the linguistic literature (Obzor predlozhenii,1965; Breusova, 2000; Grigor'eva, 2004, Arutiunova, 2016, etc.].

The "Totaldictation" annualeventhasrecently joined the practices efficient in demonstrating the size of the language community. This event started in 2011. It used to be a national event, later it became an international one. It turned to be an extraordinarily mass one (thus, 146 thousand people from 732 world cities took part in it in 2016 (http://www.nsk.aif.ru/dontknows/ kak_napisali_totalnyy_diktant-2016).

The subject of the event is mass writing of the dictation, the original text of which is created by a famous writer together with the specialists in Russian philology. The text is divided into three parts. People write these three parts in different territories of Russia and the whole world according to the sequence of time zones. This writing of the text locally takes place in the "venue" consisting of one or several premises in one building equipped with multimedia. The author reads the text via the broadcast video file and then the speaker dictates the text. The role of the speaker is usually delegated either to a philologist having an experience of dictating or to a media personality. On the one hand, it popularizes the dictation; on the other hand, it shows the speaker's recognition by the public. The online dictation on the Internet is held simultaneously with this dictation.

There are many supporting events except for the dictation itself. They include the series of training classes called "Russian on Fridays", a big conference and school-seminar concerning the organization of the Total dictation.

The scale of the event makes it equitable with the orthography reforms in the terms of the language community's ability "to manifest itself". Nevertheless, there are significant differences between the event and the reform regarding the way the language community manifests itself.

It is worth while paying attention that both the event and the reform can be called occasions.

The occasion has its grounds, aim and members, who can be described "phenomenally" regarding the scenario. It has its beneficent - the one for whom this occasion is held and, in a wider sense, the ones who care about its results.

The scenario of the reform involves the development of the blueprint for reform, discussions, making amendments, carrying out the blueprint for the reform and public reaction of the language community and its most active members, in particular.

The blueprint is developed by a few professional linguists. At present they are specialists in orthology and the official orthography commission members.

At present the discussions of the project are held in the press, other mass media and on the Internet. The amendments are made by the same professional linguists after the discussions are over. The project is approved and the bill is formed by the regulatory bodies that also work out the series of events for the implementation of the reform.

The Total dictation is prepared and held according to the following scenario.

The writer prepares the text combining its creative nature with a set of language characteristics. Thus, the writer has to apply the skills of a linguist to some extent.

A small group of linguists approves the text and offers the amendments to the text.

The writer introduces changes in the text. 
Table 1. The table shows the differences in the social roles fulfilled in two kinds of social practice by the members of two different groups

\begin{tabular}{|l|l|l|}
\hline \multicolumn{1}{|c|}{ Event Participants } & \multicolumn{1}{|c|}{ Reform } & \multicolumn{1}{c|}{ Total dictation } \\
\hline $\begin{array}{l}\text { Specialists in Russian } \\
\text { philology }\end{array}$ & $\begin{array}{l}\text { Authors of the project, critics, } \\
\text { authors of the amendments }\end{array}$ & Proof-readers, speakers, assessors \\
\hline $\begin{array}{l}\text { Teaching materials developers, } \\
\text { language }\end{array}$ & $\begin{array}{l}\text { Critics, authors of the } \\
\text { amendments }\end{array}$ & $\begin{array}{l}\text { Participants, speakers, } \\
\text { assessors }\end{array}$ \\
\hline Creative professionals & $\begin{array}{l}\text { Critics, authors of the } \\
\text { amendments } \\
\text { Journalists as communicants }\end{array}$ & $\begin{array}{l}\text { A writer as the author of the text } \\
\text { participants }\end{array}$ \\
\hline Practical philologists & - & Assessors, participants \\
\hline $\begin{array}{l}\text { Programmers dealing with the } \\
\text { language }\end{array}$ & - & $\begin{array}{l}\text { Developers of the program for the online- } \\
\text { dictation, participants }\end{array}$ \\
\hline Students of philology & - & Assessors, participants \\
\hline Communication workers & - & Participants \\
\hline The Russian language lovers & - & Participants \\
\hline
\end{tabular}

Many organizers prepare the venues for the dictation as they continue the work with the text. There are dozens of venues organized in big cities. We find ourselves in a situation when the society demands many philological managers, the people whose organizing efforts are connected with the philological event.

Therefore, the reform is an activity made by a few people for masses, for the whole Russian ethnos, which includes the Russian language community as well. The Total dictation is an activity of the great community held for the individuals aimed at defining the borders of their language competence. Here we can see the opposition of two models implemented by these practices: the model of society and the model of community described by V. Bekker (filosof. historic.ru/books/item/f00/s00/z0000048/). The reform of orthography implements the model of society, where the society is a force determining an individual's behavior. The Total dictation is a model of a community, when the society implements the individuals' demands that can hardly be implemented by the individuals themselves.

Consequently, the Total dictation as a public practice discovers new characteristics of the Russian language community:

- a writer's involvement into an active linguistic practice - creation of the text with special language characteristics exceptionally for a linguistic event;

- media-personalities' involvement in the process of language literacy popularization;

involvement of philological managers, organizing a linguistic event and providing awareness of it;

- a wider range of media philologists in addition to few linguists involved in linguistic knowledge popularization;

- mass participation of the Russian language community in the public philological practice.

\footnotetext{
Compare, for example, the Year of the Russian language, announced in relation to 2007 (Decree, 2006).

2 It is difficult to say which category the secondary specialized educational institutions should be referred to. Nominally they will be included in the same group as school teachers, though their qualification is higher. It is necessary to outline that the students' philological specialization is introduced in teacher training colleges. This indicates the high requirements to the Russian language teachers in these institutions. So, in fact, they can be referred to the same group as university professors.
} 
3 The representatives of the first three groups (14 linguists, 8 methodologists, 2 school teachers of the Russian language, 2 writers) were involved in the State orthography commission organized to develop the reform of 1964, which did not work out.

4 The notion "writer" refers to the commercial creators of the potentially original content (texts which the Internet pages are full with). Available at: http://blog.ac-u.ru/kopirajjter-ili-rajjter-mnogoznachnost-ili-neodnoznachnost/ (accessed 29 September 2016).

5 In this case I'm not discussing creativity as an art. I just mean that the members of these groups create texts in the Russian language but not about the Russian language.

\section{References}

Avrorin, V.A. (1975). Problemy izucheniya funktsional'noy storony yazyka (K voprosu o predmete sotsiolingvistiki) [Problems of Studying the Functional Aspect of the Language (To the Issue of the Object of Sociolinguistics)]. Leningrad: Nauka, 276 p.

Arutiunova, E. V. (2016). Reforma russkoi orfografii i punktuatsii 1960-kh godov: neizvestnye stranitsy istorii [The Reform of Russian Orthography and Punctuation of the 1960s: the Unknown Pages of History], In Sibirskii filologicheskii zhurnal [Siberian Philological Journal], 3, 5-16.

Basalaeva, E.G., Ruzha, O.A., Shpil'man, M. V. (2016). Russkaia orfografiia i punktuatsiia skvoz' prizmu naivnogo soznaniia [Russian Spelling and Punctuation through the Prism of Naïve Consciousness], In Sibirskii filologicheskii zhurnal [Siberian Philological Journal], 3, 59-69.

Basalaeva, E. G., Shpil'man, M. V. (2015). Mnogotochie kak ob”ekt iazykovoi refleksii v internet-diskurse [Dots as an Object of Linguistic Reflections in the Internet Discourse], In Sibirskii filologicheskii zhurnal [Siberian Philological Journal], 3, 248-255.

Bekker, V. (1995). Soobshchestvo i obshchestvo: Ob osnovnykh poniatiiakh sotsial'noi filosofii v nekotoroi istoricheskoi neizbezhnosti [Community and Society: Basic Concepts of Social Philosophy in Some Historical Inevitability]. Available at: http://www.filosof.historic.ru/books/item/f00/s00/ z0000048/ (accessed 21 September 2016).

Breusova, E.I. (2000). Rabota nad usovershenstvovaniem russkogo pravopisaniiav posleoktiabr'skii period i voprosy obshchei teorii orfograficheskikh reform [Work on Improving Russian Spelling in the Post-Revolutionary Period and the Issues of the General Theory of Spelling Reform]. Avtoreferat... kand. filol. nauk. Krasnoyarsk, 22 p. Available at: http://linguists.narod.ru/downloads4.html (accessed 21 September 2016).

Gurevich, A.Ia. (1990). Srednevekovyi mir: kul'tura bezmolvstvuiushchego bol'shinstva [The Medieval World: the Culture of Silent Majority]. Moscow, Iskusstvo, 395 p.

Grigor'eva, T.M. (2004) Tri veka russkoi orfografii [Three Centuries of Russian Spelling]. Moscow. 456 p.

Karaulov, Iu.N. (1991). O sostoianii russkogo iazyka sovremennosti [Status of the modern Russian language]. Doklad na konferentsii “Russkii iazyk i sovremennost'. Problemy i perspektivy razvitiia rusistiki" $i$ materialy pocht. diskusii v kotoroi priniali uchastie I.D. Apresian $i$ dr. [Report at the conference "Modern Russian Language. Problems and Prospects of the Russian Philology Development" and the materials of the discussion, which I.D. Apresian and others took part in]. Moscow, 65.

Lukin, P.V. (2000). Narodnye predstavleniia o gosudarstvennoi vlasti v Rossii XVII veka [People’s Ideas about State Power in Russia in the XVII Century]. Moscow, Nauka, 298 p. 
Litvak, B.G. (1971). O nekotorykh chertakh psikhologii russkikh krepostnykh pervoi poloviny XIX v. [On Some Features of Psychology of Russian Serfs in the First Half of the XIX Century], In Istoriya i psikhologiya [History and Psychology]. Moscow, Nauka, 190-214.

Obzor predlozhenii po usovershenstvovaniiu russkoi orfografii (XVIII-XX vv.) (1965). [An Overview of Proposals to Improve the Russian Spelling (XVIII-XX centuries)], Pod red. M.V. Panova. Moscow, Nauka, $500 \mathrm{p}$.

Ukaz Prezidenta Rossiiskoi Federatsii № 1488 ot 29.12.2006 «O provedenii Goda russkogo iazyka» (2006). [The Decree of the President of the Russian Federation No. 1488 dated 29.12.2006 “On Holding the Year of the Russian Language"] Moscow.

\title{
Русская языковая общественность и её массовые проявления
}

\author{
И.Е. Ким \\ Институт филологии СО РАН
}

Россия, 630090, Новосибирск, ул. Николаева, 8

Цель статьи - показать, как проявляется русская языковая общественность в наиболее масштабных филологических практиках - в реформах русской орфографии и в Тотальном диктанте, ежегодной акиии, охватившей большую русскоязычную аудиторию во всем мире. Как показало сопоставление Тотального диктанта с орфографическими реформами, близкими ему по масштабу вовлечения членов русской языковой общественности, функиии, которые выполняют в каждой из практик разные группы русской языковой общественности, различны. Новыми для филологической практики в Тотальном диктанте являются роли автора диктанта, совмещающего в тексте художественно-публичистическое содержание и заданную языковую форму, филологических менеджеров - лии, организующих филологическое мероприятие, а также по-настоящему массовое участие «безмолвствующего больщинства» (А.Я. Гуревич) русской языковой общественности.

Ключевые слова: русская языковая общественность, орфографическая реформа, Тотальный диктант, филологическая практика.

Научная специальность: 10.00.00 - филологические науки. 